The success of the congress was ensured by the excellent management by the local honorary secretary, Mrs. K. N. Quarterman.

At the general assembly the importance was stressed of the work to be done by local societies in connexion with a conference to be held during April next year at the rooms of the Zoological Society on "Nature and Countryside", at which delegates from 150 societies will discuss conservation in south-east England. The sixty-third annual congress of the Union will be held during April 1958 in Reading. F. J. EPPS

\section{MEAT HYGIENE}

$\mathrm{T}$ HIS monograph* was inspired by a seminar on "Meat Hygiene" organized by the World Health and the Food and Agriculture Organizations, and held in Copenhagen during February 1954. The names of the contributors-Albertsen, Benoit, Blom, Croft, Dolman, Drieux, Hood, Hothuis, Jepsen, Johansen, Kaplan, Koch, Scaccia-Scarafoni, Schmid, Schönberg and Thornton-not only show the truly international character of this work but also guarantee that the subject is adequately covered at the level of veterinary and medical science. The monograph is divided into sections on epidemiology, ante-mortem care, slaughter, post-mortem inspection, processing and marketing, training of personnel and meat hygiene practice. There are also some sixteen annexes on a wide variety of matters concerning meat and meat hygiene, together with a very useful bibliography. This book may be regarded as an up-to-date picture of our state of knowledge of meat hygiene, and of the risks to health by faulty hygiene under both primitive and civilized conditions. The risks implicit in primitive communities are easy to understand, but it is not generally realized that European communities are also vulnerable. In this connexion, attention is directed to the fact that large-scale handling of food, for example, school and canteen meals, presents formidable problems if food poisoning is to be avoided. The need for ante-mortem care of meat animals is emphasized, and ways in which the mechanics of loading and unloading animals into trucks and lorries can be improved are discussed. Ante-mortem inspection, so frequently neglected, is once more shown to be essential.

Perhaps the most topical section is that dealing with the design and operation of slaughter-houses. In Britain, the committee recently set up by the Government to report about the conditions in which live cattle are exported to the Continent was shocked to learn that contracts for the supply of meat for United States Forces in Europe could not be arranged from Britain direct because the hygienic standards of slaughter-houses in this country fell short of those demanded by the American Army Veterinary Corps. While this is not true of all our slaughter-houses, there is much to be learnt from the best ones in Europe.

Stunning (that is, making the animal completely unconscious) prior to slaughter is recommended. Among the methods described are the use of an electric current through the brain and of an atmo-

* World Health Organization. Monograph Series No. 33: Meat Hygiene. Contributed by V. E. Albertsen and 15 other authors. Pp. $527+2$ plates. (Geneva : World Health Organization; London :
H.M. Stationery Offce, 1957.) 30 Swiss francs; 508.; 10 dollars. sphere containing 60-75 per cent of carbon dioxide. With an electric current the voltage should be kept to $70-80 \mathrm{~V}$. in order to avoid hæmorrhage of the lungs. Moreover, it is emphasized that care in the use of electrical apparatus is necessary-for example, it should be applied to the right part of the skull. The use of carbon dioxide has proved highly successful on the large scale with pigs, the animals becoming unconscious within fifteen seconds and remaining so for about a minute.

The rapid cooling of carcases is advocated on the grounds that bacterial growth is slowed down and the carcases lose less weight by the evaporation of water from their tissues. It is emphasized that the critical zone for the growth of bacteria is from $15^{\circ}$ to $50^{\circ} \mathrm{C}$. $\left(59^{\circ}\right.$ to $122^{\circ} \mathrm{F}$.) and that in handling meat and meat products the time spent in this range of temperature must at all costs be reduced to the essential minimum. This rule is just as important, hygienically, for cooked meat as for raw meat.

It is pointed out that meat hygiene cannot be the responsibility of veterinarians alone, but that team. work between themselves, public health officers, epidemiologists, sanitary engineers, public health educators and private doctors is needed if meat hygiene is to be successful and prevent outbreaks of disense in meat-eating peoples. E. H. CALIOW

\section{COLOMBO PLAN}

\section{REPORT FOR 1955-56}

$T$ HE fifth annual report of the Consultative Com mittee for the Colombo Plan* covers the year 1955-56, during which economic indicators suggest that national incomes continued to rise at a rate slightly in excess of the rate of population growth. India's first Five Year Plan was completed with encouraging overall results, including a 35 per cent increase in the index of industrial production, and $a$ second Five Year Plan, for 1956-61, has been adopted, while in Pakistan, where the index of industrial production increased by 23 per cent in 1955, a new draft Five Year Plan is being examined by the Central and Provincial Governments. Development programmes in Burma and the Philippines were adjusted, comprehensive plans for Indonesia and Nepal are under consideration, and a National Planning Council has been established in Ceylon. External economic assistance again played an important part, and besides the equivalent of some 975 million dollars of capital aid in the form of inter-government grants and loans made available by donor members outside the area in 1955-56, loans totalling 125 million dollars were made by the International Bank for Reconstruction, and members within the area assisted one another with some capital development funds and technical aid. The numbers of people undergoing technical training and of experts employed continued to expand : there are now almost 3,000 trainees from the area studying in all parts of the world and more than 2,000 experts from abroad working in the area. The report emphasizes, however, the necessity for arduous and skilful adminis-

- The Colombo Plan for Co-operative Economic Development in South and South-East Asia-Fifth Annual Report of the Consultative Committee. Pp. 155 (Cmnd. 50.) (London: H. Stationery Office, 1957.) 5s. 6d. net. 
tration to ensure that the right sort of training is found for, or adapted to, the right sort of students, and that what is learnt is applied and passed on.

Technical assistance generally is reviewed in a separate chapter. Since 1950 technical assistance has been extended to about 11,000 trainees and about 4,000 experts have been provided, the figures under the Technical Co-operative Scheme in 1955-56 being 50 per cent higher than those for 1954-55. There has been some shift in emphasis towards engineering (particularly applied scientific research), while interest in agriculture, health and education continued and training periods tend to lengthen. Increasing use is being made of training facilities available in the region, and India has provided training facilities for 556 persons. In some fields contributions from teams of experts are becoming more frequent, and generally there is a marked emphasis in technology and industry on experts from outside the region. New ways by which technical assistance could be provided are being studied, and Australia has introduced a Correspondence Scholarship Scheme under the Colombo Plan. Much equipment has been provided for laboratories and training and research institutions and of the offers of equipment and spare parts to the value of $£ 3$ million made or under negotiation, $\mathfrak{f 6 0 0 , 0 0 0}$ is for laboratory equipment, $£ 1,300,000$ for training purposes and $£ 375,000$ for research equipment.

Technical assistance continues to form a large part of United States aid to the countries of south and south-east Asia, for which more than 40 million dollars were made available in the year ending June 30,1956 , a major objective being the development of self-supporting educational and training facilities to the point where more and better training can be provided from the countries' own resources. Up to that date the United States Government technical co-operation programmes financed the training of nearly 4,000 persons and the provision of more than 1,200 United States experts in the countries concerned, as well as making available a wide range of demonstration and training equipment. Many contracts, usually for three years, have been concluded between universities in south and south-east Asian countries and those in the United States, covering assistance in improving curricula, provision of training facilities in United States universities and interchange of teaching staff.

The United States Government and its Specialized Agencies are another major source of technical assistance, and stress is laid on the value of the reports and economic surveys produced by these bodies. The United Kingdom is the principal source of technical assistance to Singapore, the Federation of Malaya, Sarawak and North Borneo, and bilateral technical assistance agreements have been made between certain Colombo Plan countries and countries which are not members of the Plan. To avoid overlapping and ensure that such assistance is, so far as possible, complementary, liaison officers are maintained with the Council for Technical Cooperation in Colombo by both the United States Government and the United Nations Technical Assistance Board.

A chapter of special interest in the report is that which reviews the tasks ahead. While much progress has been made in the economic growth of the region, there is an increasing awareness of the need for maintaining flexibility in furthering development programmes, while consolidating existing gains. The problem of developing sufficient opportunities for productivity employing the growing human resources of the area remains, while the varying stages and forms of development and the wide range of experience within the region provide new opportunities for co-operation among the countries of south and southeast Asia. Future development will tend to require more cornplex and difficult decisions in such matters as the extent to which the fruits of development can and should be devoted to consumption rather than investment, the pattern of investment, and the impact of a country's development programme upon its external situation and the economic life of other countries. The mobilization of additional depart. mental energies will be required in both the public and the private sectors, and while the flow of external resources to the countries in the region has so far been largely in the form of grants, increased opportunities may develop for drawing on toreign private investment and on private and public loans as sources of external capital. The record of achievement set forth in this report gives reason to believe that, however great may be the difficulties ahead, they will be overcome.

\section{THE FUTURE OF REINDEER IN SCOTLAND}

$\mathrm{W}$ HEN reindeer were introduced into Scotland some ten years ago, a significant factor was that the various ground, rock and tree lichens eaten by reindeer play little part in the diet of red deer, roe deer, sheep, or other indigenous animals. In places the lichens form a carpet several inches deep. It was this discovery of untouched lichens that gave rise to the reindeer experiment now proceeding in Scotland; its course has been described by N. N. P. Utsi (Oryx, 4, No. 1; April 1957).

In northern Scandinavia there are more than 600,000 domesticated reindeer and in the northern U.S.S.R. approximately two million, valued for their meat, skins, milk and hair, and for transport. These benefits have led to imports of reindeer in Alaska, Canada and South Georgia. Usually described as an arctic animal, the reindeer is widely found in the sub-arctic and in zones regarded as 'temperate'.

There were many reindeer in Scotland in prehistoric times, and these were probably hunted with red deer. Why the wild reindeer died out while the red deer remained is unknown. Utsi suggests that reindeer meat was probably more popular, and the pre-firearm techniques of the chase were not adequate to eliminate the fleeter red deer.

Why should reindeer now be 'forced' to live in Scotland when they had once died out? There are a number of reasons. Good meat can more easily be obtained at the time it is wanted, and be carefully handled, when it comes from a tame or at least halftame animal. Reindeer owners, whatever their language or origin, eat mainly or only reindeer meat ; their farming neighbours often buy reindeer meat, in spite of owning meat-producing animals them. selves. In the cities and towns of Scandinavia it is rated a delicatesse ; the tender tongue is a delicacy in Europe. Reindeer hide also tans to a fine chamois-like surface suitable for ladies' gloves and handbags. 